\title{
Phenotypic and Genetic Parameter Estimates for Racing Traits of Thoroughbred Horses in Turkey
}

\begin{abstract}
This study was carried out to investigate the fixed effects influencing racing traits of Thoroughbred horses and to estimate the genetic parameters for these traits, which are needed to design breeding programmes. The racing records used in the study were obtained from the Turkish Jockey Club. The traits used in the study were racing time, best racing time, rank, annual earnings, earnings per start, log annual earnings and log earnings per start. Genetic parameters were estimated by REML procedure using DFREML programme. The effects of age and sex were significant for each trait. The effect of year was significant on earning traits and time traits, except for best racing time on turf track. The effects of month on time traits were also significant. Heritability estimates of entire dataset were $0.317,0.467,0.132,0.194,0.291,0.188$ and 0.341 for racing time, best racing time, rank, annual earnings, earnings per start, $\log$ annual earnings and log earnings per start, respectively. Estimates of repeatability varied from 0.293 to 0.465 for racing time, from 0.373 to 0.531 for best racing time and from 0.215 to 0.232 for rank depending on the dataset used in the analyses.
\end{abstract}

Key Words: thoroughbred horses, environmental effects, heritability, repeatability, racing traits

\section{Zusammenfassung}

Titel der Arbeit: Schätzung phänotypischer und genetischer Parameter für Rennleistungen von Vollblutpferden in der Türkei

Das Ziel der Studie ist die Untersuchung der Einflüsse fixer Effekte auf die Schätzung phänotypischer und genetischer Parameter von Rennleistungen von Vollblutpferden. Diese Parameter sind bei der Gestaltung von Zuchtprogrammen erforderlich. Die Daten für die Rennleistungen wurden vom türkischen Jockeyclub bereitgestellt. Einbezogen wurden die Merkmale: Rennzeit, beste Rennzeit, Platzziffer, jährliche Gewinnsumme und der Gewinn je Start. Die Parameter wurden mittels der REML-Prozedur unter Nutzung des Programms DFREML geschätzt. Die Einflüsse Alter und Geschlecht waren für alle Merkmale ebenso signifikant wie der Einfluss des Rennjahres auf die Gewinnsumme und die Rennzeiten mit Ausnahme des Merkmals der besten Rennzeit. Ebenso signifikant war der Monatseinfluss auf die Rennzeit. Für die Heritabilität wurden in der Reihenfolge für die Merkmale Rennzeit, beste Rennzeit, Platzziffer, jährliche Gewinnsumme, Gewinnsumme je Start, Log. der jährlichen Gewinnsumme und Log. Gewinnsumme je Start folgende Werte geschätzt: 0,317, 0,467, 0,132, 0,194, 0,291, 0,188 und 0,341. Die Werte für die Wiederholbarkeit variierten für die Rennzeit zwischen 0,293 bis 0,465 , für die beste Rennzeit von 0,373 bis 0,531 und für die Platzziffer von 0,215 bis 0,232 .

Schlüsselwörter: Vollblutpferde, Umwelteffekte, Heritabilität, Wiederholbarkeit, Rennleistungsmerkmale

1. Introduction

Horse racing is one of the most popular sports in Turkey. Official racings are organised by Turkish Jockey Club (TJK) since 1954. Although horse racing in Turkey is highly organized; and nutrition, training methods, veterinary procedures and track conditions have been improved, no scientific study has been carried out to improve the racing performance of racehorses by a selection programme.

In order to evaluate racing performance genetically, it is necessary to have a measure of performance. In the literature, various traits like racing time, best racing time, rank, 
position rates, annual earnings, earning per start were used to measure racing performance (RICARD, 1998). Racing time in each race is the only direct measure of speed and is a suitable quantitative measure that can be used to evaluate the genetic racing performance of horses (SCHWARK et al., 1992; MORITSU et al., 1994; OKI et al., 1994; RÖHE et al., 2001). However, the reported heritability estimates for time traits were generally low (HINTZ, 1980; MORITSU et al., 1994; MOTA et al., 1998). Therefore, most of the recent studies focused on earning or rank traits, and different transformations of these traits (ARNASON, 1999; BUGISLAUS et al., 2004; SAASTAMOINEN and OJALA, 1991; SOBCZYNSKA and KOWNOCKI, 1997; VILLELA et al., 2002).

The objectives of this study were to investigate the fixed effects influencing racing traits of Thoroughbred horses and to estimate the genetic parameters for these traits, which are needed to design breeding programmes.

\section{$2 . \quad$ Materials and Methods}

The racing records of Thoroughbred horses used in this study were obtained from the Turkish Jockey Club, and included official racings from January 1998 to December 2003. Information available for each race included the distance, track type and date of the race, and age, sex, official finish time, rank and earnings of the horses. The pedigree information of the horses was also included. Dataset included the racing distances of 1200 m, 1300 m, 1400 m, 1500 m, 1600 m, 1700 m, 1800 m, 1900 m, 2000 m, 2100 m, 2200 m and $2400 \mathrm{~m}$. Horse racings in Turkey were ran both in dirt and turf tracks. The records of horses that could not complete the race were deleted from the dataset. Edited dataset comprised racing records of 4034 horses. 430 horses ran only in dirt track and 324 horses ran only in turf track, while 3280 horses participated in both dirt and turf track races. As prize money is given only to the first four horses in each race in Turkey, 3156 of the horses evaluated in the current study earned money.

The traits used in the study were racing time, best racing time, rank, annual earnings, earnings per start (EPS), log annual earnings (log earnings) and log earnings per start (log EPS).

A horse's best racing time was the fastest time of the horse over several races during a racing year. To compare the racing times of a horse over different distances and to determine the annual best racing time, a linear adjustment for racing distances was used. However, unadjusted data were used in analyses. Dataset for racing time, best racing time and rank were edited and analysed according to dirt races, turf races and entire dataset (dirt + turf). Earnings were in Turkish Lira and so they were firstly changed to US Dollar according to rate of exchange at the race day. The entire dataset used for analyses comprised 75065 racing records for racing time and rank, 8906 records for best racing time and 6410 records for earning traits. The dataset also consisted of 4034 horses from 633 sires and 2171 dams for racing time, best racing time and rank, 3156 horses from 557 sires and 1857 dams for earning traits.

Variance components and genetic parameters were estimated by the Restricted Maximum Likelihood (REML) method for a single trait animal model using derivativefree process. To identify fixed effects to be included in the animal models, preliminary the least-squares analysis of variance was carried out by the GLM procedure in SPSS 12.0 program. The effects of age (2-7 years and older), sex (male or female) and year (1998 to 2003) were fitted to the mathematical model used in preliminary analyses for 
each trait. To account the track condition indirectly, the effect of month was fitted to model for time traits. Least-squares models for racing time, best racing time and rank also included the effect of number of competitors in the race (5 to 20). In the analyses of entire dataset for racing time, best racing time and rank, track type (dirt or turf) was fitted to the model as a fixed effect. The preliminary least-squares analyses for time traits also included linear and quadratic covariate due to racing distance. The effects of year on best racing time of turf track and on rank were not significant. The effects of track type on rank for entire dataset and number of competitors on racing time and best racing time were also not significant. Therefore, these effects were dropped from the animal models, which were used to estimate genetic parameters.

The animal model used to estimate the variance components was:

$\boldsymbol{Y}=\mathbf{X} \boldsymbol{\beta}+\mathbf{Z}_{\mathbf{a}} \mathbf{a}+\mathbf{Z}_{\mathbf{p e}} \mathbf{p e}+\mathbf{e}$

Where $Y$ is the vector of observations; $\beta$, a, pe, and e are vectors of fixed effects, direct additive genetic effects (animal), permanent environmental effects and the residual effects, respectively; $X, Z_{a}$, and $Z_{p e}$ are incidence matrices relating observations to $\beta$, a and pe, respectively.

The DFREML 3.0 program of Meyer (1998) was used to estimate genetic parameters. The search for the maximum of the likelihood was stopped if the variance of the simplex function values were less than $10^{-8}$. Restarts were performed to confirm global convergence.

Heritability was estimated by dividing direct additive genetic variance $\left(\sigma_{\mathrm{a}}{ }^{2}\right)$ by phenotypic variance $\left(\sigma_{\mathrm{P}}{ }^{2}\right)$ and repeatability was estimated from the ratio between the sum of direct additive genetic and permanent environmental variances $\left(\sigma_{\mathrm{a}}{ }^{2}+\sigma_{\mathrm{pe}}{ }^{2}\right)$ and phenotypic variance.

Table 1

Least-squares means (LSM) of age and sex of horse on racing time and best racing time (LSM für Alter und Geschlecht der Pferde für Rennzeit und beste Rennzeit)

\begin{tabular}{|c|c|c|c|c|c|c|c|c|c|c|c|c|}
\hline \multirow{3}{*}{ Effects } & \multicolumn{6}{|c|}{ Racing time, $\mathrm{s}$} & \multicolumn{6}{|c|}{ Best racing time, $\mathrm{s}$} \\
\hline & \multicolumn{2}{|c|}{ Dirt } & \multicolumn{2}{|c|}{ Turf } & \multicolumn{2}{|c|}{ Entire dataset } & \multicolumn{2}{|c|}{ Dirt } & \multicolumn{2}{|c|}{ Turf } & \multicolumn{2}{|c|}{ Entire dataset } \\
\hline & $\mathrm{n}$ & $\overline{\mathrm{LSM}}$ & $\mathrm{n}$ & $\overline{\mathrm{LSM}}$ & $\bar{n}$ & LSM & $n$ & LSM & $\bar{n}$ & LSM & $\bar{n}$ & $\overline{L S M}$ \\
\hline$\overline{\text { Age }}$ & \multicolumn{2}{|c|}{$* * *$} & \multicolumn{2}{|c|}{$* * *$} & \multicolumn{2}{|c|}{$* * *$} & \multicolumn{2}{|c|}{$* * *$} & \multicolumn{2}{|c|}{$* * *$} & \multicolumn{2}{|c|}{$* * *$} \\
\hline 2 & 4371 & $110.7^{\mathrm{d}}$ & 4911 & $108.4^{\mathrm{d}}$ & 9282 & $108.9^{d}$ & 1750 & $96.5^{c}$ & 1786 & $95.9^{d}$ & 2245 & $94.6^{\mathrm{c}}$ \\
\hline 3 & 14661 & $109.7^{c}$ & 13979 & $106.9^{\mathrm{c}}$ & 28640 & $107.6^{\mathrm{c}}$ & 2619 & $95.3^{b}$ & 2529 & $94.2^{\mathrm{c}}$ & 2857 & $93.1^{b}$ \\
\hline 4 & 9822 & $108.9^{b}$ & 7864 & $106.3^{b}$ & 17686 & $107.0^{b}$ & 1651 & $94.8^{\mathrm{a}}$ & 1411 & $93.6^{b}$ & 1813 & $92.4^{\mathrm{a}}$ \\
\hline 5 & 5593 & $108.8^{a}$ & 4096 & $106.0^{\mathrm{a}}$ & 9689 & $106.8^{\mathrm{a}}$ & 871 & $94.6^{\mathrm{a}}$ & 713 & $93.6^{b}$ & 975 & $92.2^{\mathrm{a}}$ \\
\hline 6 & 3073 & $108.9^{a b}$ & 2068 & $106.0^{\mathrm{a}}$ & 5141 & $106.9^{a b}$ & 469 & $94.8^{\mathrm{a}}$ & 339 & $93.2^{\mathrm{a}}$ & 525 & $92.3^{\mathrm{a}}$ \\
\hline $7+$ & 3041 & $109.8^{c}$ & 1586 & $106.4^{\mathrm{b}}$ & 4627 & $107.5^{c}$ & 442 & $95.5^{b}$ & 280 & $93.8^{\mathrm{bc}}$ & 491 & $92.8^{b}$ \\
\hline Sex & \multicolumn{2}{|c|}{$* * *$} & \multicolumn{2}{|c|}{$* * *$} & \multicolumn{2}{|c|}{$* * *$} & \multicolumn{2}{|c|}{$* * *$} & \multicolumn{2}{|c|}{$* * *$} & \multicolumn{2}{|c|}{$* * *$} \\
\hline Male & 24617 & 109.1 & 17492 & 106.5 & 42109 & 107.1 & 4337 & 94.8 & 3716 & 93.9 & 4878 & 92.7 \\
\hline Female & 15944 & 109.9 & 17012 & 106.9 & 32956 & 107.7 & 3465 & 95.7 & 3342 & 94.2 & 4028 & 93.2 \\
\hline
\end{tabular}

3.

\section{Results}

The least-squares means (LSM) of the fixed effects for racing time and best racing time were presented in Tables 1 and 2. There was a decline in racing time and best racing time from young to intermediate age, and an increase through seven years and older. The effect of sex on time traits was significant, and male horses were much faster than female ones. The effect of year was also significant for time traits, except for best racing time on turf track. Racing time and best racing time on dirt track were shorter in spring and autumn 
months than winter and summer months. Both racing time and best racing time on turf track were lowest in January and February, and improved gradually until June. However, they decreased from July to December.

Table 2

Least-squares means (LSM) of year and month on racing time and best racing time (LSM für Jahr und Monat der Rennzeit und beste Rennzeit)

\begin{tabular}{|c|c|c|c|c|c|c|c|c|c|c|c|c|}
\hline \multirow{3}{*}{ Effects } & \multicolumn{6}{|c|}{ Racing time, s } & \multicolumn{6}{|c|}{ Best racing time, $\mathrm{s}$} \\
\hline & \multicolumn{2}{|c|}{ Dirt } & \multicolumn{2}{|c|}{ Turf } & \multicolumn{2}{|c|}{ Entire dataset } & \multicolumn{2}{|c|}{ Dirt } & \multicolumn{2}{|c|}{ Turf } & \multicolumn{2}{|c|}{ Entire dataset } \\
\hline & $\mathrm{n}$ & LSM & $\mathrm{n}$ & LSM & $\mathrm{n}$ & LSM & $\mathrm{n}$ & LSM & $\mathrm{n}$ & LSM & $\mathrm{n}$ & LSM \\
\hline Year & \multicolumn{2}{|c|}{$* * *$} & \multicolumn{2}{|c|}{$* * *$} & \multicolumn{2}{|c|}{$* * *$} & \multicolumn{2}{|c|}{$* * *$} & \multicolumn{2}{|c|}{ NS } & \multicolumn{2}{|c|}{$* * *$} \\
\hline 1998 & 4800 & $109.2^{\mathrm{a}}$ & 3362 & $106.6^{b}$ & 8162 & $107.1^{\mathrm{a}}$ & 845 & $95.1^{\mathrm{ab}}$ & 751 & 94.0 & 979 & $92.7^{\mathrm{a}}$ \\
\hline 1999 & 5326 & $109.4^{b}$ & 4697 & $106.3^{a}$ & 10023 & $107.2^{b}$ & 1004 & $94.8^{a}$ & 945 & 93.8 & 1170 & $92.6^{\mathrm{a}}$ \\
\hline 2000 & 6336 & $109.1^{\mathrm{a}}$ & 5613 & $106.7^{b}$ & 11949 & $107.3^{b}$ & 1189 & $95.0^{\mathrm{ab}}$ & 1049 & 94.1 & 1340 & $92.8^{a b}$ \\
\hline 2001 & 7275 & $109.5^{c}$ & 6311 & $107.1^{\mathrm{c}}$ & 13586 & $107.7^{c}$ & 1442 & $95.2^{b}$ & 1294 & 94.2 & 1635 & $93.0^{\mathrm{bc}}$ \\
\hline 2002 & 8492 & $109.8^{\mathrm{d}}$ & 6990 & $106.7^{b}$ & 15482 & $107.7^{c}$ & 1616 & $95.6^{c}$ & 1458 & 94.0 & 1841 & $93.1^{b c}$ \\
\hline 2003 & 8332 & $109.8^{d}$ & 7531 & $106.7^{b}$ & 15863 & $107.8^{d}$ & 1706 & $95.7^{c}$ & 1561 & 94.1 & 1941 & $93.2^{c}$ \\
\hline Month & \multicolumn{2}{|c|}{$* * *$} & \multicolumn{2}{|c|}{$* * *$} & \multicolumn{2}{|c|}{$* * *$} & \multicolumn{2}{|c|}{$* * *$} & \multicolumn{2}{|c|}{$* * *$} & \multicolumn{2}{|c|}{$* * *$} \\
\hline Jan. & 5293 & $109.8^{\text {ef }}$ & 622 & $111.4^{\mathrm{j}}$ & 5915 & $108.6^{g}$ & 1126 & $95.6^{d}$ & 91 & $99.4^{\mathrm{g}}$ & 547 & $94.7^{\mathrm{e}}$ \\
\hline Feb & 4246 & $109.7^{\mathrm{e}}$ & 1160 & $111.3^{\mathrm{j}}$ & 5406 & $109.0^{\mathrm{h}}$ & 739 & $95.4^{\mathrm{d}}$ & 116 & $99.8^{\mathrm{g}}$ & 335 & $94.5^{\mathrm{e}}$ \\
\hline Mar. & 4126 & $109.5^{\mathrm{d}}$ & 2290 & $107.8^{h}$ & 6416 & $108.4^{\mathrm{f}}$ & 588 & $95.6^{d}$ & 266 & $95.2^{\mathrm{e}}$ & 440 & $94.6^{\mathrm{e}}$ \\
\hline Apr. & 3164 & $109.0^{\mathrm{a}}$ & 1803 & $106.9^{g}$ & 4967 & $107.8^{\mathrm{e}}$ & 612 & $94.7^{\mathrm{ab}}$ & 248 & $93.1^{\mathrm{d}}$ & 350 & $92.4^{b c}$ \\
\hline May & 2072 & $109.2^{\text {bc }}$ & 3979 & $104.0^{b}$ & 6051 & $106.2^{\mathrm{a}}$ & 353 & $94.7^{\mathrm{ab}}$ & 1009 & $91.2^{\mathrm{a}}$ & 1040 & $91.5^{\mathrm{a}}$ \\
\hline June & 2198 & $109.8^{\text {ef }}$ & 4096 & $103.5^{\mathrm{a}}$ & 6294 & $106.1^{\mathrm{a}}$ & 282 & $96.2^{\mathrm{e}}$ & 988 & $91.3^{a}$ & 1009 & $92.0^{a}$ \\
\hline July & 2258 & $109.9^{\mathrm{f}}$ & 4209 & $104.0^{b}$ & 6467 & $106.6^{b}$ & 342 & $96.7^{\mathrm{f}}$ & 1021 & $91.8^{b}$ & 1060 & $92.5^{c}$ \\
\hline Aug. & 2349 & $109.2^{\text {bc }}$ & 3995 & $104.3^{c}$ & 6344 & $106.5^{b}$ & 443 & $95.2^{\mathrm{cd}}$ & 867 & $92.1^{\mathrm{c}}$ & 926 & $92.5^{c}$ \\
\hline Sep. & 2641 & $109.1^{\mathrm{ab}}$ & 4455 & $104.7^{d}$ & 7096 & $106.8^{c}$ & 584 & $94.8^{a b}$ & 964 & $92.0^{\mathrm{bc}}$ & 1038 & $92.3^{b c}$ \\
\hline Oct. & 2919 & $109.5^{d}$ & 4549 & $105.0^{\mathrm{e}}$ & 7468 & $107.2^{d}$ & 642 & $94.5^{\mathrm{a}}$ & 1053 & $92.0^{\text {bc }}$ & 1141 & $92.2^{b}$ \\
\hline Nov. & 4066 & $109.3^{\mathrm{cd}}$ & 2087 & $106.3^{f}$ & 6153 & $107.7^{\mathrm{e}}$ & 947 & $94.6^{a}$ & 349 & $92.9^{d}$ & 567 & $92.3^{b}$ \\
\hline Dec. & 5229 & $109.4^{\mathrm{cd}}$ & 1259 & $110.8^{1}$ & 6488 & $108.5^{f}$ & 1144 & $95.0^{\mathrm{bc}}$ & 86 & $97.5^{\mathrm{f}}$ & 453 & $93.4^{d}$ \\
\hline
\end{tabular}

NS: $\mathrm{P}>0.05, * * *: \mathrm{P}<0.001$

The LSM of age and sex for rank, annual earnings and EPS were presented in Table 3. Seven years and older horses showed the lowest performance for rank. This age group also had the lowest EPS. Although annual earnings of 2-year old horses were lower than those of 3, 4, 5 and 6-year old ones, the differences among these age groups for EPS were not significant. Male horses were significantly superior to the females for rank, annual earnings and EPS.

Estimates of variance components and genetic parameters for each trait were presented in Tables 4 and 5. Heritability estimates of entire dataset were $0.317,0.467$ and 0.132 for racing time, best racing time and rank, respectively. Heritability estimates of dirt track were higher than those of turf track for racing time and best racing time, while they were similar for rank. Estimates of repeatability varied from 0.293 to 0.465 for racing time, from 0.373 to 0.531 for best racing time and from 0.215 to 0.232 for rank depending on the dataset used in the analyses. 
Table 3

Least-squares means (LSM) of age and sex of horse on rank and earning traits (LSM für Alter und Geschlecht der Pferde für Platzziffer und Gewinnsumme)

\begin{tabular}{|c|c|c|c|c|c|c|c|c|c|c|}
\hline \multirow{3}{*}{ Effects } & \multicolumn{6}{|c|}{ Rank } & \multirow{2}{*}{\multicolumn{2}{|c|}{$\begin{array}{c}\text { Annual earnings, } \\
\text { USD } \\
\end{array}$}} & \multirow{2}{*}{\multicolumn{2}{|c|}{$\begin{array}{c}\text { Earnings per start, } \\
\text { USD }\end{array}$}} \\
\hline & \multicolumn{2}{|c|}{ Dirt } & \multicolumn{2}{|c|}{ Turf } & \multicolumn{2}{|c|}{ Entire dataset } & & & & \\
\hline & $n$ & LSM & $\mathrm{n}$ & LSM & $\mathrm{n}$ & LSM & $\mathrm{n}$ & LSM & $n$ & LSM \\
\hline \multirow[t]{6}{*}{ Age } & \multicolumn{2}{|c|}{$* * *$} & \multicolumn{2}{|c|}{$* * *$} & \multicolumn{2}{|c|}{$* * *$} & \multicolumn{2}{|c|}{$* * *$} & \multicolumn{2}{|c|}{$* * *$} \\
\hline & 4371 & $6.52^{\mathrm{ab}}$ & 4911 & $6.72^{\mathrm{a}}$ & 9282 & $6.73^{a}$ & 1674 & $27585.9^{c}$ & 1674 & $4621.6^{a}$ \\
\hline & 14661 & $6.50^{a}$ & 13979 & $6.72^{a}$ & 28640 & $6.72^{\mathrm{a}}$ & 2178 & $47066.8^{a}$ & 2178 & $4355.7^{\mathrm{a}}$ \\
\hline & 9822 & $6.64^{\mathrm{ab}}$ & 7864 & $6.86^{\mathrm{b}}$ & 17686 & $6.85^{b}$ & 1190 & $49672.7^{\mathrm{a}}$ & 1190 & $4356.6^{a}$ \\
\hline & 5593 & $6.53^{a}$ & 4096 & $6.62^{a}$ & 9689 & $6.68^{a}$ & 688 & $51166.0^{a}$ & 688 & $4538.5^{a}$ \\
\hline & 3073 & $6.68^{b}$ & 2068 & $6.54^{\mathrm{a}}$ & 5141 & $6.73^{a}$ & 377 & $42882.3^{b}$ & 377 & $4111.7^{a}$ \\
\hline $7+$ & 3041 & $7.08^{c}$ & 1586 & $7.23^{c}$ & 4627 & $7.25^{c}$ & 303 & $30472.2^{c}$ & 303 & $2225.4^{b}$ \\
\hline$\overline{\text { Sex }}$ & \multicolumn{2}{|c|}{$* * *$} & \multicolumn{2}{|c|}{$* * *$} & \multicolumn{2}{|c|}{$* * *$} & \multicolumn{2}{|c|}{$* * *$} & \multicolumn{2}{|c|}{$* * *$} \\
\hline Male & 24617 & 6.35 & 17492 & 6.70 & 42109 & 6.63 & 3633 & 47163.1 & 3633 & 4738.4 \\
\hline Female & 15944 & 6.97 & 17012 & 6.86 & 32956 & 7.02 & 2777 & 35785.5 & 2777 & 3331.5 \\
\hline
\end{tabular}

Table 4

Estimates of genetic parameters for racing time, best racing time and rank (standard errors in parentheses) (Schätzung genetischer Parameter für die Merkmale Rennzeit, beste Rennzeit, und Platzziffer (Standardfehler in Klammern))

\begin{tabular}{ccccccccccc}
\hline & \multicolumn{3}{c}{ Racing time } & \multicolumn{3}{c}{ Best racing time } & \multicolumn{3}{c}{ Rank } \\
\cline { 2 - 11 } Item $^{\mathrm{a}}$ & Dirt & Turf & $\begin{array}{c}\text { Entire } \\
\text { dataset }\end{array}$ & Dirt & Turf & $\begin{array}{c}\text { Entire } \\
\text { dataset }\end{array}$ & Dirt & Turf & $\begin{array}{c}\text { Entire } \\
\text { dataset }\end{array}$ \\
\hline$\sigma_{\mathrm{a}}{ }^{2}$ & 6.906 & 3.369 & 5.730 & 6.668 & 3.071 & 5.640 & 1.640 & 2.180 & 1.784 \\
$\sigma_{\mathrm{pe}}{ }^{2}$ & 1.201 & 0.887 & 0.757 & 0.634 & 0.933 & 0.401 & 1.131 & 1.151 & 1.120 \\
$\sigma_{\mathrm{e}}{ }^{2}$ & 9.347 & 10.268 & 11.602 & 6.281 & 6.721 & 6.043 & 9.588 & 11.053 & 10.598 \\
$\sigma_{\mathrm{p}}{ }^{2}$ & 17.454 & 14.525 & 18.089 & 13.583 & 10.725 & 12.084 & 12.359 & 14.385 & 13.503 \\
$\mathrm{~h}_{\mathrm{d}}{ }^{2}$ & 0.396 & 0.232 & 0.317 & 0.491 & 0.286 & 0.467 & 0.133 & 0.152 & 0.132 \\
$\mathrm{pe}^{2}$ & $(0.029)$ & $(0.025)$ & $(0.022)$ & $(0.045)$ & $(0.035)$ & $(0.044)$ & $(0.019)$ & $(0.020)$ & $(0.016)$ \\
$\mathrm{r}$ & 0.069 & 0.061 & 0.042 & 0.047 & 0.087 & 0.033 & 0.092 & 0.080 & 0.083 \\
& $(0.025)$ & $(0.022)$ & $(0.018)$ & $(0.040)$ & $(0.033)$ & $(0.038)$ & $(0.016)$ & $(0.016)$ & $(0.013)$ \\
\hline
\end{tabular}

${ }^{\mathrm{a}} \sigma_{\mathrm{a}}{ }^{2}:$ direct additive genetic variance, $\sigma_{\mathrm{pe}}{ }^{2}:$ permanent environmental variance, $\sigma_{\mathrm{e}}{ }^{2}:$ error variance, $\sigma_{\mathrm{p}}{ }^{2}:$ phenotypic variance, $\mathrm{h}_{\mathrm{d}}{ }^{2}:$ direct heritability, $\mathrm{pe}^{2}: \sigma_{\mathrm{pe}}{ }^{2} / \sigma_{\mathrm{p}}{ }^{2}$, r: repeatability

Table 5

Estimates of genetic parameters for earning traits (standard errors in parentheses) (Schätzung genetischer Parameter für die Merkmale der Gewinnsumme (Standardfehler in Klammern))

\begin{tabular}{ccccc}
\hline Item $^{\mathrm{a}}$ & Annual earnings & Earnings per start & $\log$ earnings & $\log$ EPS \\
\hline$\sigma_{\mathrm{a}}{ }^{2}$ & 535503981.7 & 9513452.8 & 0.0733 & 0.1152 \\
$\sigma_{\mathrm{pe}}{ }^{2}$ & 342294452.3 & 5112748.4 & 0.0469 & 0.0228 \\
$\sigma_{\mathrm{e}}{ }^{2}$ & 1886930686.0 & 18125439.4 & 0.2696 & 0.1994 \\
$\sigma_{\mathrm{p}}{ }^{2}$ & 2764729120.7 & 32751640.6 & 0.3897 & 0.3373 \\
$\mathrm{~h}_{\mathrm{d}}{ }^{2}$ & 0.194 & 0.291 & 0.188 & 0.341 \\
& $(0.039)$ & $(0.046)$ & $(0.036)$ & $(0.042)$ \\
$\mathrm{pe}^{2}$ & 0.124 & 0.156 & 0.120 & 0.068 \\
$\mathrm{r}$ & $(0.036)$ & $(0.043)$ & $(0.035)$ & $(0.039)$ \\
\hline
\end{tabular}

${ }^{\mathrm{a}} \sigma_{\mathrm{a}}{ }^{2}$ : direct additive genetic variance, $\sigma_{\mathrm{pe}}{ }^{2}:$ permanent environmental variance, $\sigma_{\mathrm{e}}{ }^{2}$ : error variance, $\sigma_{\mathrm{p}}{ }^{2}:$ phenotypic variance, $\mathrm{h}_{\mathrm{d}}{ }^{2}:$ direct heritability, $\mathrm{pe}^{2}: \sigma_{\mathrm{pe}}{ }^{2} / \sigma_{\mathrm{p}}{ }^{2}$, r: repeatability 
Direct additive genetic effect contributed about $19 \%$ of the phenotypic variance for annual earnings and log annual earnings. Estimates of heritability were 0.291 and 0.341 for EPS and $\log$ EPS, respectively. Estimates of repeatability for EPS and log EPS were higher than those of annual earnings and log annual earnings.

\section{$4 . \quad$ Discussion}

According to the preliminary analyses, which were carried out to determine the fixed effects included in the animal models, the effect of age was significant for each trait. The tendency, which improve with age till six year of age and then decline, was observed for racing time, best racing time and annual earnings. However, similar pattern of change could not be found for rank and EPS. Seven years and older horses showed the lowest performance for these traits, and differences between this age group and others were significant. The significant effects of age was also reported for racing times of Arabian horses (EKİZ et al., 2004), for best racing times of Thoroughbred horses (MORITSU et al., 1994) and for racing times of Thoroughbred horses (OKI et al., 1994). MORITSU et al. (1994) reported that best racing times of Thoroughbred horses tended to become shorter as the horses aged. EKIZ et al. (2004) and MARTIN et al. (1996) also reported similar pattern of changes for racing times of Arabian and Thoroughbred horses, respectively. However, MOTA et al. (1998) for best racing time and VILLELA et al. (2002) for racing time and rank found the effect of age to be non-significant for Thoroughbred and Quarter horses, respectively.

The significant superiority of males for each trait found in the current study were in agree with reports of EKIZ et al. (2004) for racing times of Arabian horses, reports of VILLELA et al. (2002) for racing times of Quarter horses and reports of MOTA et al. (1998) for best racing times of Thoroughbred horses. In the study of MORITSU et al. (1994), the effect of sex was reported to be non-significant for distance of $1200 \mathrm{~m}$ and to be significant for distance of $1800 \mathrm{~m}$. In contrast with the current study, VILLELA et al. (2002) reported the non-significant effects of sex on rank.

The effects of month on time traits appear to be different for turf and dirt tracks in the current study. Both racing time and best racing time on dirt track were shorter in spring and autumn months. Otherwise, the shortest racing time for turf track was observed in June, and gradually it became slower by month after and before June. OKI et al. (1994) reported significant effects of month on racing time for both turf and dirt tracks. However, this effect was reported to be non-significant for best racing times of Thoroughbred horses (MOTA et al., 1998).

The significant differences between racing years for time traits found in the current study disagree with the reports for Thoroughbred horses by MOTA et al. (1998) and OKI et al. (1994), and agree with the reports of SUBEVA (1990). Similar to the current study, EKIZ et al. (2004) for racing times of Arabian horses, OKI et al. (1994) for racing times of Thoroughbred horses, MOTA et al. (1998) and MORITSU et al. (1994) for best racing times of Thoroughbred horses reported that horses were faster on turf track than dirt track. The results of the current study showed that the effect of number of competitors in race was not significant for racing time and best racing time, and was significant for rank. MOTA et al. (1998) reported similar result for best racing time.

Estimate of heritability obtained from analyses of entire dataset for racing time (0.317) was higher than those of 0.17 and 0.24 reported for Quarter horses by VILLELA et al. 
(2002) and BUTTRAM et al. (1989), respectively. EKIZ et al. (2004) estimated heritability between 0.175 and 0.304 depending on racing distance for Arabian horses. HINTZ (1980) reported lower estimate (0.15) for Thoroughbred horses and similar estimate (0.32) for Trotters compared with the current study. The estimate of heritability for racing time on dirt track (0.396) in the current study was higher than estimates of OKI et al. (1995) for dirt track, which varied between 0.086 and 0.217 depending on racing distance. On the other hand, estimate of heritability for racing time on turf track $(0.231)$ was within the range of estimates reported by OKI et al. (1995) for racing time on turf track (0.081-0.254).

Estimate of heritability for best racing time (0.467) was also higher than the literature estimates, except reports of OJALA et al. (1987), which varied from 0.28 to 0.50 depending on model for Finnish horses. Estimates of heritability for best racing times of Thoroughbred horses were reported to be 0.12 by MOTA et al. (1998), 0.23 by HINTZ (1980), 0.11 and 0.09 for racing distances of $1200 \mathrm{~m}$ and $1800 \mathrm{~m}$ by MORITSU et al. (1994). ARNASON (1999), OJALA (1987) and HINTZ (1980) also reported lower estimates for best racing times of Trotters. Relatively higher estimates of heritability for time traits found in the current study than those of literature estimates could be due to the lack of a systematic selection programme, which was based on accurate estimates of genetic parameters, for these traits for Thoroughbred horses in Turkey.

While estimates of heritability for time traits were medium to high, estimates for rank were low. Estimates of heritability for rank were similar to those reported by SAASTAMOINEN and OJALA (1991) and VILLELA et al. (2002). However, SOBCZYNSKA and KOWNACKI (1997) reported estimate of 0.25 for Polish purebred Arab horses.

Estimates of heritability obtained from the analysis of dirt track dataset were clearly higher than those of turf track for racing time and best racing time, whereas they were similar for rank. In contrast with the current study, estimates of heritability for racing time on dirt and turf tracks were reported to be similar by OKI et al. (1995).

Estimates of heritability for earning traits varied from low to medium in literature. OJALA (1987) reported estimates of 0.07 and 0.17 for earnings, 0.19 and 0.12 for log earnings, 0.13 and 0.25 for EPS and 0.22 and 0.16 for log EPS of Finnish and Standardbred horses, respectively. ARNASON (1999) estimated heritability to be 0.36 for earnings and 0.23 for EPS of Swedish Standardbred Trotters. BUGISLAUS et al. (2004) found a heritability of 0.097 for Log of earnings of German thoroughbreds. SOBCZYNSKA and KOWNACKI (1997) also reported estimates to be low (0.22) for log annual earnings of Polish purebred Arab horses. Estimates of heritability obtained in the current study for earning traits were within the range of literature estimates summarised above. However, HINTZ (1980) reported relatively higher estimates for log earnings of Thoroughbred horses (0.49) and Trotters (0.41). Estimate of heritability for EPS (0.291) was higher than that of annual earnings (0.194). OJALA (1987) also reported that transformations applied to earning traits increased the heritability estimates.

Estimates of repeatability for racing time in the current study were in agree with those of BUTTRAM et al. (1989), who reported estimates of 0.32 for Quarter horses and GROSU et al. (2000), who reported estimates of 0.29 for Romanian Trotters. However, current estimates were lower than those of VILLELA et al. (2002) for Quarter horses, SAASTAMOINEN and OJALA (1991) for Trotters and OKI et al. (1995) for 
Thoroughbred horses. The repeatability estimates for final rank were lower than 0.44 reported for Quarter horses (VILLELA et al., 2002), 0.29 reported for Trotters (SAASTAMOINEN and OJALA, 1991) and 0.25 reported for Polish Purebred Arab horses (SOBCZYNSKA and KOWNACKI, 1997).

Permanent environmental effects on racing performance may include such factors as early nutrition, injury, owner and trainer (BUTTRAM et al., 1989). In the current study, estimates of $\mathrm{pe}^{2}$ for time traits were lower than those of rank and earning traits, except log EPS. These results do not agree with the results of VILLELA et al. (2002), who reported higher estimates for racing time.

According to the results of the current study, the lowest heritability was estimated for rank. Annual earnings and log earnings have also lower estimates compared with time traits, EPS and log EPS. Best racing time has yielded the highest estimates of heritability. Furthermore, time traits have nearly normal distribution and are a better quantitative measure for statistical analysis than earning traits that differ greatly from a normal distribution. These facts suggest that best racing time is the most appropriate trait among that investigated in the current study, and selection for this trait might result in more genetic improvement than other traits.

\section{References}

ARNASON, T.:

Genetic evaluation of Swedish standard-bred trotters for racing performance traits and racing status. J. Anim. Breed. Genet. 116 (1999), 387-398

BUGISLAUS, A.-E.; ROEHE, R.; UPHAUS, H.; KALM, E.:

Development of genetic models for estimation of racing performances in German thoroughbreds. Arch. Tierz., Dummerstorf 47 (2004) 6, 505-516

BUTTRAM, S.T.; WILSON, D.E.; WILLHAM, R.L.:

Genetics of racing performance in the American Quarter horse: III. Estimation of variance components. J. Anim. Sci. 66 (1989), 2808-2816

EKIZ, B.; KOCAK, O.; DEMIR, H.:

Estimates of genetic parameters for racing performances of Arabian horses. Turk J. Vet. Anim. Sci. (2004), in press

GROSU, H.; STANESCU, M.; KREMER, V.; LUNGU, S.; PANA, C.; RADOI, C.:

Genetic parameters for repeated performances of the Romanian Trotters. In: $51^{\text {st }}$ Annual Meeting of the European Association for Animal Production, The Hague, The Netherlands (2000), 356

HINTZ, R.L.:

Genetics of performance in the horse. J. Anim. Sci. 51 (1980), 582-594

MARTIN, G.S.; STRAND, E.; KEARNEY, M.T.:

Use of statistical models to evaluate racing performance in thoroughbreds. J. Am. Vet. Med. Assoc. 209 (1996), 1900-1906

MEYER, K.:

DFREML Programs to Estimate Variance Components by Restricted Maximum Likelihood Using a Derivative - Free Algorithm, User Notes (1998)

MORITSU, Y.; FUNAKOSHI, H.; ICHIKAWA, S.:

Genetic evaluation of sires and environmental factors influencing best racing times of Thoroughbred horses in Japan. J. Equine Sci. 2 (1994), 53-58

MOTA, M.D.S.; OLIVERIA, H.N.; SILVA, R.G.:

Genetic and environmental factors that affect the best time of Thoroughbred horses in Brazil. J. Anim. Breed. Genet. 115 (1998), 123-129

OJALA, M.:

Heritabilities of annually summarized race records in trotters. J. Anim. Sci. 64 (1987), 117-125

OJALA, M.J.; VAN VLECK, L.D.; QUASS, R.L.:

Factors influencing best annual racing time in Finnish horses. J. Anim. Sci. 64 (1987), 109-116 
OKI, H.; SASAKI, Y.; WILLHAM, R.L.:

Genetic parameter estimates for racing time by restricted maximum likelihood in the Thoroughbred horse of Japan. J. Anim. Breed. Genet. 112 (1995), 146-150

OKI, H.; SASAKI, Y.; WILLHAM, R.L.:

Genetics of racing performance in the Japanese Thoroughbred horse: II. Environmental variation of racing time on turf and dirt tracks and the influence of sex, age, and weight carried on racing time. J. Anim. Breed. Genet. 111 (1994), 128-137

RICARD, A.:

Developments in the genetic evaluation of performance traits in horses. In: $6^{\text {th }}$ World Congress on Genetics Applied to Livestock Production, Armidale (1998), 388-395

RÖHE, R.; SAVAS, T.; BRKA, M.; WILLMS, F.; KALM, E.:

Multiple-trait genetic analyses of racing performance of German trotters with disentanglement of genetic and driver effects. Arch. Tierz., Dummerstorf 44 (2001) 6, 579-587

SAASTAMOINEN, M.T.; OJALA, M.J.:

Estimates of genetic and phenotypic parameters for racing performance in young trotters. J. Agric. Sci. Finland. 41 (1991), 427-436

SCHWARK, H:J.; PETZOLD, P.; KARWARTH, M.:

Untersuchungen zur Objektivität und zur züchterischen Effektivität der stationären Eigenleistungsprüfungen von Hengsten der Reitpferderassen. Arch. Tierz., Dummerstorf 35 (1992) 1/2, 97-106

SOBCZYNSKA, M.; KOWNACKI, M.:

Genetic aspects of racing performance in Polish purebred Arab horses. I. Genetic parameters. J. Appl. Genet. 38 (1997), 179-186

SUBEVA, I.:

Effect of the family of horses of the east Bulgarian breed on racing time. Anim. Sci. 2 (1990), 71-75

VILLELA, L.C.V.; MOTA, M.D.S.; OLIVEIRA, H.N.:

Genetic parameters of racing performance traits of Quarter horses in Brazil. J. Anim. Breed. Genet. 119 (2002), 229-234

Received: 2004-10-11

Accepted: 2005-03-03

Author's addresses

Dr. BÜLENT EKİZ

Istanbul Üniversitesi Veteriner Fakültesi

Zootekni Ana Bilim Dalı, Avcilar

34320-İstanbul/Türkei

E-mail: bekiz@istanbul.edu.tr

Doc. Dr. ALPER YILMAZ

Istanbul Üniversitesi Veteriner Fakültesi

Zootekni Ana Bilim Dalı, Avcilar

34320-İstanbul/Türkei
Dr. ÖMÜR KOCAK

Istanbul Üniversitesi Veteriner Fakültesi

Zootekni Ana Bilim Dalı, Avcilar

34320-İstanbul/Türkei 